\title{
English and Vietnamese Female Names: A Comparison and Contrast
}

\author{
Thao Minh Thi Le
}

\author{
Department for Scientific \\ Research and External Relations, \\ Hanoi Open University, Vietnam \\ Corresponding Author
}

\section{Ngoc Thi Pham}

Korean Department, Hanoi University, Vietnam

DOI: https://doi.org/10.36941/jesr-2020-0112

\begin{abstract}
Onomastics as a branch of linguistics and sociolinguistics has been recognized as being important in disclosing interesting features of the language and culture of a community. This research aims to identify the features of female names in the two language systems of English and Vietnamese. After investigating the names of 12,879 female students attending two universities in England and 12,936 attending three universities in Vietnam, the study reveals interesting results concerning the linguistic features, meanings and cultural characteristics offemale names in English and Vietnamese. In relation to those contents, the research provides in-depth analyses on the social and historical development of the two countries.
\end{abstract}

Keywords: Onomastics, inflectional, monosyllabic, naming taboo, sociolinguistics

\section{Introduction}

Names in a language are not only a means of addressing but also conveying historical, social and cultural values featuring the community that speaks the language. The study of names and naming, referred to as onomastics, is divided into anthroponomastics - the study of names of persons - and toponomastics - the study of names of places (Colman, 2014). Arguments raised around names and naming practices have further divided onomasticians into opposing schools of thoughts. Researchers including Nyström (2016), Colman (2014) and van Langendonck and van de Velde (2016) support the view that names carry meaning while many others, for example Mill (1884) and Kripke (1972), are against this. Other research interests in the field are on the distinction between lexical and grammatical nouns, naming taboo, monosyllable or polysyllable names, or naming origins. This has contributed to expand onomastics into an important branch of linguistics and sociolinguistics.

Within the realm of onomastics, proper names have not received comparable attention as other subjects of study. van Langendonck (2007) comments that proper names belong to the system of natural languages and thus are worth linguistic attention. By researching the linguistic features and socio-cultural values of Vietnamese and English names, this study is expected to enrich relevant 
onomastics literature. The study examines the origins, structures, and cultural characteristics of Vietnamese and English names and compare the two naming systems in terms of structures, meanings, and socio-cultural traits.

\section{Literature Review}

\subsection{Onomastics and the study of proper nouns}

Onomastics is defined as the study of proper nouns and their origins (Algeo, 1992). Onomastic research has drawn on a variety of methods to elucidate such topics as the history and etymology of names, the meaning and grammar of names, and the social relevance of naming practices (Farkas, 2017). Early onomastic research generally employed corpus linguistic methods to identify the roles of names in language use (Motschenbacher, 2020a). While those previous studies do not often consider the context of use, they have contributed an understanding of proper names by investigating the linguistic forms and functional aspects of names, including their grammatical, semantic, and pragmatic functions. To understand the popularity of names or their grammatical construction, most corpus-based name studies draw on the analysis of how often certain onomastic phenomena occur in a text corpus (Laversuch, 2010; McClure, 1981; Motschenbacher, 202ob; Oelke, Kokkinakis, \& Malm, 2012; Ström \& Levin, 2019; van Dalen-Oskam, 2012). This has been combined with a concordance analysis to shed light on the semantic characteristics that are associated with names and to disclose their connotation meanings (Motschenbacher, 2020a). Analyses on collocation have also been used to explore the lexical or grammatical items collocating with a particular name (Vuillemot, Clement, Plaisant, \& Kumar, 2009). Onomastic researchers then use keywords analyses by comparing two or more corpora to determine how the context of use shapes the use of names or how name-related language changes (Vartiainen, 2019).

Proper nouns have been studied not only by philosophers, logicians, anthropologists and psychologists, but also sporadically by linguists (Motschenbacher, 2020a; Sloat, 1969). It is generally agreed that proper nouns are a universal linguistic category and share the key features with common nouns and personal pronouns (Motschenbacher, 2020a; van Langendonck, 2007). They, for example, can combine with adjectives or modifiers and possess grammar-gendered forms. Some researchers distinguish proper nouns from proper names, explaining that the former refers to names of certain entities, such as persons, cities, or countries, while the latter refers to a more abstract class of naming expressions that can combine proper nouns and common nouns (Motschenbacher, 2020a). In this research, proper names and proper nouns are treated synonymously as in the following remarks by van Langendonck (2007, p. 116):

A proper name is a noun that denotes a unique entity at the level of established linguistic convention to make it psychologically salient within a given basic level category [pragmatic]. The meaning of the name, if any, does not (or not any longer) determine its denotation [semantic]. An important formal reflex of this pragmatic-semantic characterisation of names is their ability to appear in such close appositional constructions as the poet Burns, Fido the dog, the River Thames, or the City of London [syntactic].

In the definition above, van Langendonck (2007) holds the view that names comprehensively bear pragmatic, semantic, and syntactic features. Imomov and Kuldashev (2020) further add that proper nouns constitute an open part of speech that comprise nouns. Proper nouns, while being lexical rather than grammatical, do not carry as much lexical meaning as nouns in general. 
Table 1. Groups of entities that proper nouns can refer to (Le, 2013; T. T. Pham, 1996)

\begin{tabular}{clll}
\hline$\#$ & Category & Examples in English & Examples in Vietnamese \\
1 & Names of persons & Ruth Thomas Jones & Chí Phèo \\
2 & Names of animals & Rex & Mực (Lão Hạc) \\
3 & Names of geographical sites & The Red Sea, Mars & Sông Hồng, Núi Bà Đen \\
4. & Names of administration units & England, London, Edinburgh & Anh, Luân Đôn, Ninh Thuận \\
5 & Names of organisations & Democrats, the United Nations & Hội phụ nữ Việt Nam \\
6 & Names of infrastructures & The Taj Mahal, The Eiffel Tower & địa đạo Củ Chi, \\
7 & Names of historical events and laws & The Civil War & Phong trào Xô viết Nghệ Tĩnh \\
8 & Month, days of week, holiday & Monday, Christmas & thứ Hai, Giáng sinh \\
9 & Religions, deities, scriptures & God, Christ & Chúa, Người \\
10 & Awards, vehicle models & Nobel Prize, Rolls Royce & giải thướng Quả cầu vàng \\
11 & Legal or governmental documents & & Bộ luật Dân sự \\
\hline
\end{tabular}

Table 1 lists eleven groups of entities that proper nouns can refer to, illustrated with examples in English and Vietnamese. As shown in the table, apart from personal names, the capitalization of proper nouns in English is rather different from that in Vietnamese. For example, in English, the first letters of all mentioned words are capitalized (the United Nations, the Civil War), whereas, in Vietnamese, only the first letter of the first word in a chunk is capitalized (Liên hiệp quốc, Bộ luật Dân sự). Personal names, particularly given names like Mary or John, are generally considered to be the most prototypical name categories as they exhibit all of the criteria outlined above (Tse, 2000; van Langendonck, 2007). Meanwhile, place names and others like brand names or language names are less prototypical (Tse, 2000).

\subsection{The functional, grammatical, semantic, and structural features of proper nouns}

Functionally, proper nouns are words that name specific people, organizations, or places. Names are assigned with several functions, the two most important of which are referring (referential) and addressing (vocative) (Bhat, 1979; Coates, 2006; Lyons, 1977). While there is shared agreement with regard to the former function, there is certain contention on the latter function of names. Specifically, most scholars who study names and naming practices agree that the most fundamental function of names is to draw listeners' attention to the presence and existence of the person being named (Lyons, 1977). In this case, names are independent of the immediate situational context. Each name has its own features for sound or meaning. For the addressing function, many researchers (for example Anderson, 2015; Hough, 2000; van Dalen-Oskam, 2012) have questioned whether only personal names can be used to address the target listeners but not the inanimate objects' names. The major linguistic feature of names is the initial capitalisation in writing, which serves the purpose of distinguishing a proper noun from a common noun, for example the name Rosemary as opposed to rosemary as a type of herb. Names are subject to word formation processes, including suffixation, shortening or phonological modification as in English names (Imomov \& Kuldashev, 2020) or compounding as in Vietnamese names (V. K. Nguyen, 2010), as in shown the example below.

$\begin{array}{lll}\text { Full Form } & \text { Hypocorisms } & \\ \text { John } & \text { Johnny } & \text { (suffixation) } \\ \text { Joseph } & \text { Joe } & \text { (shortening) } \\ \text { Richard } & \text { Dick } & \text { (shortening and phonological modification) } \\ \text { Thu } & \text { Hoài Thu } & \text { (compounding) }\end{array}$

Grammatically, studies on the grammar of proper nouns have mostly explored the prototypical features of proper names. In the Vietnamese language, it is common for Vietnamese speakers to add an intensifying adverb very (rất) in front of a place name to describe something typical of the region such as rất Huế or rất Hà Nội (Le, 2002). Several personal names are also used as adjectives, verbs or nouns in related social contexts. V. K. Nguyen (2010) gives an interesting example of Chí Phèo, a 'devil' 
character in the literary work by Nam Cao, a well-known Vietnamese writer. The name has been used in today's society as an adjective to refer to pathetic or immoral behaviors as in thói Chí Phèo (Chi Pheo habit) or thằng Chí Phèo (people with bullying and anti-social behaviors).

Concerning the internal structure, proper nouns are classified as either mono- or poly-lexemic, sometimes preceded with an article, as in London, John Smith or the Red Sea. Personal names can be preceded by a title, as in Mrs. Smith or Aunt Mary. In the Vietnamese language, it is common for a title to be placed in front of names, especially names of older people, as a means of showing respect. The most widely used titles are kinship terms, such as dì [Aunt], cô [Aunt], cậu [Uncle], bác [Uncle], which can be used to address not only relatives but also stranger (Tran, 1984). However, this use of titles is regarded controversial as it can imply social and gender biases (Motschenbacher, 2020a; V. K. Nguyen, 2010; van Langendonck, 2007).

Semantically, proper nouns are mainly used to refer to a particular entity but often not to describe it (Anderson, 2007; van Langendonck, 2007). Often, the question of interest is whether proper names carry meaning. On one side, there are arguments that proper names do not have lexical meanings (Kripke, 1972; Mill, 1884). Mill (1884) gives an example of two proper names, George and King George III, to explain that the name George can only be used to refer to a person, yet not to his position while the name King George III cannot convey any more information about that person. On the other hand, several other researchers, including Nyström (2016), Colman (2014), and van Dalen-Oskam (2012), share the opinion that proper names denote presuppositional meaning. This means a name is connected to a certain fundamental concept category which is presupposed for them rather than asserted. Smith, for instance, is commonly identified as a person's surname, Birmingham as a place name, Thames as a river name, Lassie as the name of a dog, though they may be contextually incorrect (sometimes Stephanie may be the name of a dog, or Birmingham may be a person's surname). However, whether these presuppositions are semantic or pragmatic in nature has not been confirmed. Also, what these presuppositions actually belong to or originate from remains a question (van Langendonck, 2007).

The other types of meaning of proper nouns that have been explored are denotational and connotational meanings (Nystrom 2006). Denotation refers to the relation between a certain form and the class of entities to which it can be attached, and hence remains unchanged through contexts. For example, Lulogooli people's names mostly have denotative meaning related to travelling, natural phenomena, poverty, seasons, personality and so forth (Olenyo, 2011). Mugera in their language means river, Inzala hunger, Akidiva perish, and Agesa harvest. Connotation, on another note, refers to the associations that proper nouns have depending on users' knowledge and experience. Connotative meanings can be individual or shared among groups of people. For example, in Germany, English-based male names such as Justin or Kevin and French-based female names such as Chantal or Jacqueline are stereotypically associated with a lower social class whereas names like Ronny, Mandy, Nancy or Doreen are associated with a higher social class (Hayn, 2016).

Structurally, a person's full name comprises three main parts, first name, middle name and family name. The functions and structures of each vary from culture to culture. Specifically, in many European and American societies, family names can be used to address a person with titles such as Mr., Mrs., or Professor, Doctor. Only in formal situations of communication are surnames with related titles used. According to McClure (2016), family names remain unpopular before the $13^{\text {th }}$ century and most people only had given names. Not until the end of the $16^{\text {th }}$ century did family names of the English appear in the upper class under the widespread dominance of European culture and laws. Gradually, family names become increasingly popular among all classes in the society. In the Vietnam language, however, family names are almost never used in daily life communication since there is only a small number of family names that exist, which makes it challenging to use family names to distinguish one person with another. It is, for example, estimated that $40 \%$ of Vietnamese people share the surname Nguyễn (Le, 2002; T. T. Pham, 2005; Vu, 2005). Instead, Vietnamese surnames serve the purpose of upholding a family ancestral value. 


\subsection{The cultural aspect of naming practices}

Culturally, names have been considered one of the most crucial treasures given to a person. Findings by Algeo (1992), Anderson (2015), and Hayn (2016) reveal that a person without a name is of lower social status than those with a name. As such, naming practice is indispensable in one culture. Naming differs from culture to culture in different ways. Several cultures are patronyms (Asian and European), others are metronyms, others are mixed. Some assign more than two names for children, others only one. Some children have their names within one week or more after birth.

In Vietnam, naming practices have experienced changes since the feudal society. As described by $\mathrm{Vu}$ (2005), during this time, after a child was born, he or she was given an unofficial name. Not until the child was registered for school was an official name given to him and written in the clan's book. All boys but girls could have their names recorded in the book. Vietnamese people in rural areas had the habit of naming their children with offensive names to avoid mishaps or even bad lucks. This practice is believed to have originated from China. It is reasoned that the Chinese often named their children with unwanted names so that devils and ghosts had to stay away from their children and thus leave their children safe and sound. Much as these two naming practices have disappeared gradually in Vietnam in the modern time, a few instances can still be found in rural areas and even in big cities.

Another culture-related phenomenon is naming taboo, which is a socio-cultural taboo against speaking or writing the given names of noble persons in Confucian countries, such as China, Korea or Vietnam. There are three types of naming taboo, namely the naming taboo of the state, the naming taboo of the clan, and the naming taboo of the holiness. Yeon (2014) suggests three major ways to avoid violating the naming taboo. One way is to change the script or written character so that it only bears a synonymous sound. The others are to leave the character as blank and to omit a stroke in the character. In Vietnam, naming avoidance is as important as naming practice. This practice is rooted from the Nguyen feudal time when all names had to be different from those of the royal family, saints, and their own ancestral family. Meanwhile, Phillip and Weller (1964) assert that no evidence in name avoidance is found in the naming practice of the English. Instead, English people tend to name their children after saints to show their admiration and belief in God. The English are also very proud to be named after their beloved predecessors in the family, such as their great grandparents, grandparents, or parents. Vietnamese people avoid names after temples whereas people in many other countries use names of places to name human beings. Alexandria in Egyptian and Britany in French are two common instances to cite.

With regard to gender in personal names, in Vietnamese, the middle name Thi is the most common for females whereas Văn is typically used for males $(\mathrm{Vu}, 2005)$. This naming tradition is recorded to date back to 475-331 BC when the feudalistic male-dominant mindset was exercised. Văn means literature and schooling, which was characteristically assigned for only men at that time. Thi, on the other hand, was used as a means of identifying women. It is estimated that more than $50 \%$ of Vietnamese women have this middle name (Thien, 2019). The middle name Thi was knowingly borrowed from the Chinese language. However, in the Chinese culture, Thi was only given to Chinese women after they got married and had their husband's family name added in front of theirs. For example, in Vưong Đào Thị, Vương is the husband's family name and Đào is the woman's. Dao (196o) notes that Thi is an old-fashioned word used as a third-person female to indicate despise. In Vietnamese literary works, several female characters whose lives were underrepresented had their names associated with Thị. Some typical instances are Thị Mầu and Thị Kính in the Vietnamese folk tale Quan Âm Thị Kinh, Thị Nở in the short story Chi Pheo by Nam Cao, or Thị in the work Vợ Nhặt [The wife I picked] by author Kim Lân. Nowadays, the use of Văn and Thị in male and female names is not as common as in the past. The discrimination against women whose names include Thị has also faded in line with the reduced gender discrimination in the modern Vietnamese society. Apart from these two middle names that denote gender differences, it is increasingly common for the same middle names to be used for both males and females, which makes it difficult to distinguish genders through names. 


\section{Research Methodology}

\subsection{Sampling}

This study has three main aims, firstly to compare the linguistic features of English and Vietnamese female names, secondly to provide an insight into the meanings of Vietnamese and English female names, and thirdly to explore the similarities and differences in the socio-cultural characteristics reflected through English and Vietnamese female names.

Data were collected from the databases of 12,879 female students attending two universities in England, namely the University of the West of England and Cranfield University, and 12,936 Vietnamese female students attending three universities in Vietnam. The three Vietnamese universities, Hanoi Open University, Hue Science University and Ho Chi Minh Open University, represent the northern, central and southern regions of the country.

\subsection{Research methods}

With the data collected from the databases, the study employed the standard analytical techniques commonly used in linguistics and social science studies for data analysis. This involved categorizing names into different linguistic functions, counting the frequencies of the categories, and comparing their characteristics. Following this, using the available information, the researchers identified and invited 100 female students to participate in an interview conducted via Zoom. The research participants were invited to respond to 10 interview questions on the naming practices of the two countries, England and Vietnam. Current characteristics of Vietnamese and English names were mainly investigated. However, where possible, relevant research on both the synchronic and diachronic bases of the research subjects was also analysed to gain a thorough and comprehensive understanding of English and Vietnamese female names.

\section{Findings and Discussion}

\subsection{Linguistic features of English and Vietnamese female names}

Onomastic studies in both English and Vietnamese (for example Bardsley, 1815; Imomov \& Kuldashev, 2020; Le, 1992, 2002, 2013; Luong, 1990; McClure, 1981, 2014; T. T. Pham, 1996; Tran, 1984; Vu, 2005) have revealed that the common structure of all female names comprises three components, namely family name, middle name and given name. Each component is a single naming unit which can function independently in terms of semantic meanings. Regarding name structures, both English and Vietnamese female names display two patterns, namely (i) family name + middle name + given name and (ii) family name + given name. The order of family name and given name, however, are positioned differently in the two languages.

From a morphological perspective, English features inflectional language whereas Vietnamese is characterized as an isolating language. However, both languages can be considered to have morphemes, the smallest language units which carry meaning and constitute a word (Courtenay, 1972; T. C. Nguyen, 1975). In English, there are two types of morphemes, namely the root and the affix. The root morpheme carries the basic meaning of a word whereas the affixes add meaning or change the part of speech of the root. One root can have more than one affix, which can be a prefix added before the root or a suffix which is added after the root. English female names are not the exception of this rule, as seen in Table 2. Vietnamese, on another note, is a tonal language with the sound system of six distinctive tones (Edmondson \& Nguyen, 1997) (Table 3). Vietnamese names can be monosyllabic or polysyllabic, meaning having one or more than one syllables (V. K. Nguyen, 1999; T. T. Pham, 2005). 
Table 2. Examples of inflections in English female names

\begin{tabular}{llll}
\hline Morpheme types & Examples & Affix & Origin \\
\multirow{2}{*}{ Root } & Dan- & Danielle, Daniella, Dannii & Hebrew \\
& Dio- & Dionne, Dion, Dionna & Ancient Greek \\
\hline \multirow{2}{*}{ Prefix } & Eu- & Eunice & Ancient Greek \\
& Ger- & Geraldine & Old English \\
\multirow{2}{*}{ Suffix } & $-\mathrm{a}$ & Paula, Emma, Pamela & Latin \\
& $-\mathrm{el}$ & Hazel, Edel, Sanel & Old English \\
\hline
\end{tabular}

Table 3. The Vietnamese tone system (Thompson, 2005, p. 20)

\begin{tabular}{|c|c|c|}
\hline Tone in Vietnamese & Corresponding mark & Description \\
\hline Sắc & & High Rising Tenseness \\
\hline Huyền & ' & Low Trailing Laxness, Breathiness \\
\hline Hỏi & ? & Mid-Low Dropping Tenseness \\
\hline Ngã & $\sim$ & High Rising Glottalisation \\
\hline Bằng & Unmarked & High-Mid Trailing-Falling Laxness \\
\hline Nặng & . & Low Dropping Glottalisation, Tenseness \\
\hline
\end{tabular}

On the basis of morphemes being the smallest component for both English and Vietnamese names, this research classifies English and Vietnamese female names into (i) single and complex given names, (ii) single, complex and no middle names, and (iii) single and complex family names.

\subsubsection{Linguistic features of English female names}

The section below reports findings for English female names in a respective order of given names, middle names, and family names.

Of all the English given names surveyed, single names were the far more popular than complex names, accounting for $98.6 \%$ and $1.4 \%$ respectively. Complex names exist into four patterns. The most common one consists of one root and one affix such as Dorothy = Doro (root) + thy (suffix). Eighty-six names, accounting for $0.67 \%$ of all names were found to feature this structure. The second most common complex names, making up $0.34 \%$ (44 names), consist of two or more roots such as Allison= Alli (root) + son (root). Next came the structure involving two single words such as Lesley-Ann =Lesley (word) + Ann (word) with 35 names (o.27\%). Lastly, complex names coin one single word with one complex word. Names like Cherry-McKrein = Cherry (single word) + -McKrein (root-root word) accounted for $\mathbf{0 . 1 2} \%$ ( 15 names). If we consider the root as R, prefix as $\mathrm{P}$, affix as A and single word as $\mathrm{W}$ then we have Table 4. As shown in this table, the least popular model of family name belonged to Model 6 with one name, accounting for $0.01 \%$. The highest frequency model of English female complex names was number 1 with 5929 names, comprising 39.83\%, in which the names with a suffix far outnumbered those with a prefix, 5848 to 81 respectively. This was followed by model 2 and 3 with 3604 and 57 names, comprising $27.98 \%$ and $0.44 \%$ accordingly.

Table 4. Structures of English female names

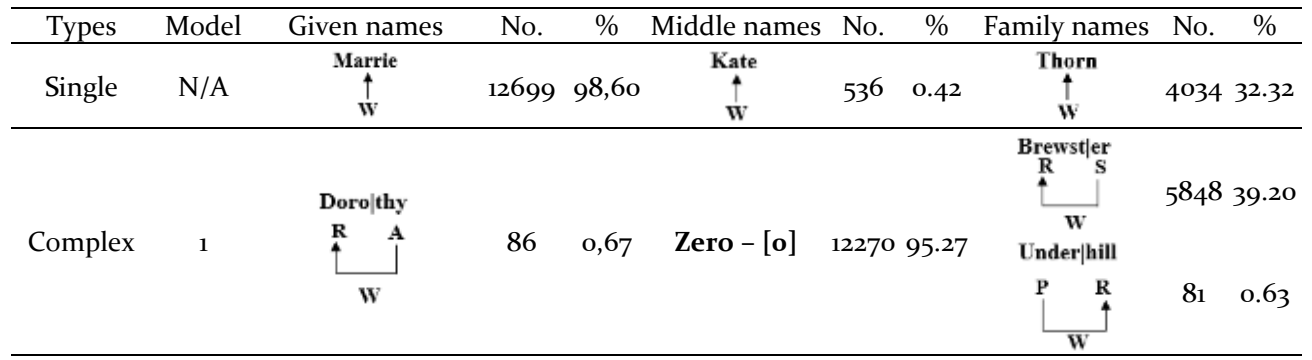




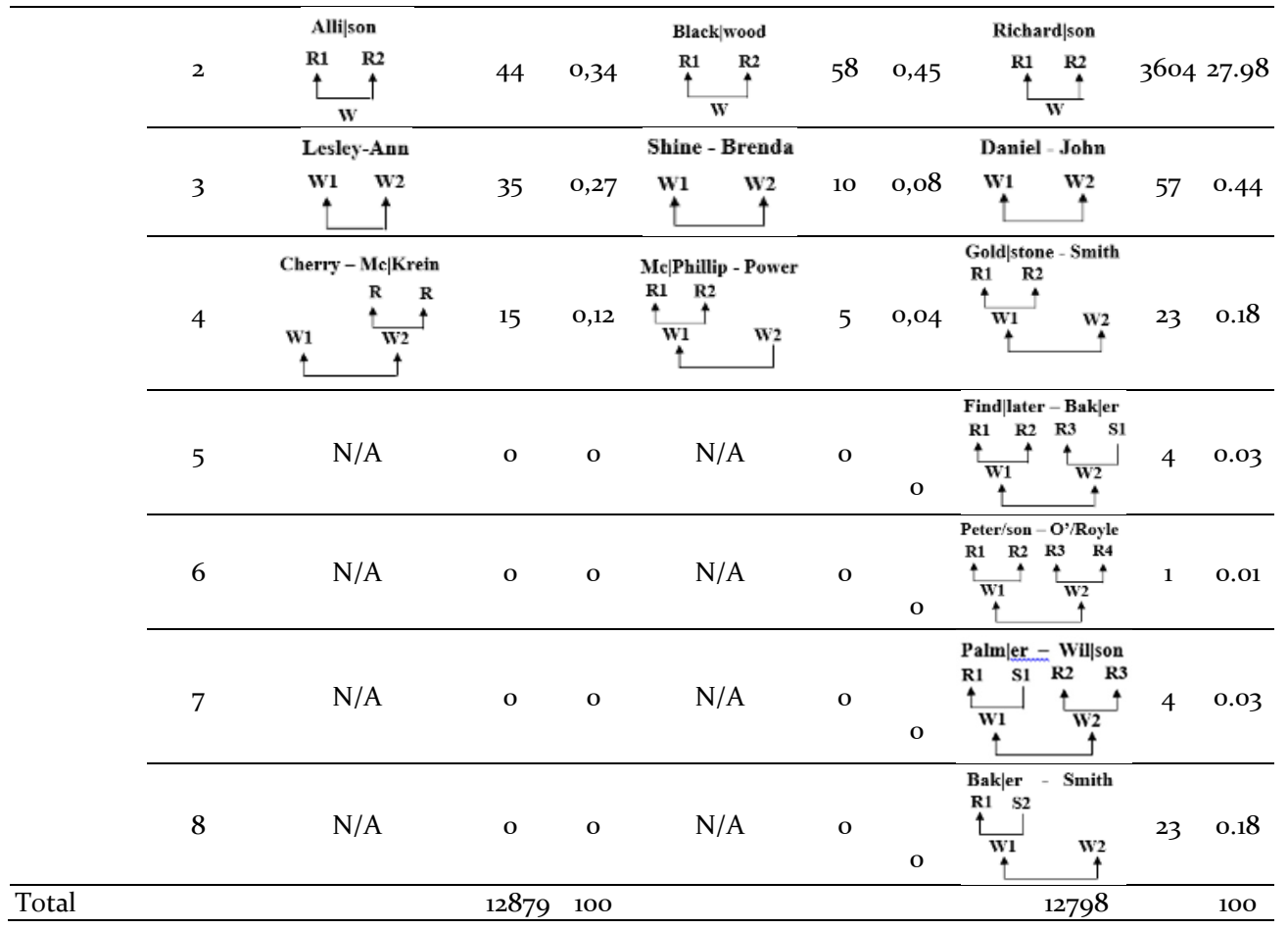

Affixation rules in English allows English female given names to be formed in unlimited number of ways. However, English people tend to choose names previously available instead of newly coined ones. Jessica, for instance, was reported to be of the top ten most popular names in England and Wales from 1996 to 2015 on behindthename.com. The name Jessica was recorded the most popular in 1996 with $2.12 \%$ among English female names. In this study, out of 614 English female names, the name Emelia appeared 14 times (2.12\%). The result resonates with V. K. Nguyen (2010) who finds that Emilia has been of the top popularity since 1994 .

Concerning middle names, the study identifies three naming patterns, namely English female names with no middle name, with one middle name, or with complex middle name. Complex middle names are defined as those with two or more morphemes. In the database of 12,879 English female names used for this study, 12,270 names do not include a middle name, accounting for $95.27 \%$. Among 614 names of English females born into the year 1975, only 64 had a middle name, accounting for $10.42 \%$. Generally, female names with a middle name are found on legal documents such as passports or identity cards but not on birth or death certificates. Middle names are often omitted or contracted, for example from Julie Allison Madine to Julie A. Maline, indicating that they are not considered important to users. Regarding female names with a single middle name, 536 cases are identified, which comprise an insignificant percentage of $4.16 \%$. English female names with a complex middle name have the lowest frequency, with $0.56 \%$. Complex middle names can be in the form of two roots as in Blackwood = Black (root) + wood (root), two single words as in Shine-Brenda $=$ Shine (word) + Brenda (word), or one single and one complex as in McPhillip-Power $=[M c(r o o t)+$ Phillip (root) $]+$ Power (word). The popularity of English female names without a middle name can be due to historical reasons when middle names were previously viewed as disclosing a person's gender, artistic views, or social status (McClure, 2016; Tse, 2005). However, identifying English female middle names was not an easy task due to the difficulty in deciding whether a section of the name belonged to the middle name or the family name. For example, in the name Hannah Louise Wakefield, it is challenging to decide 
whether Louise is the middle name or a part of the family name. Any deterministic conclusion has to be reached by means of directly inquiring the person with that name. This is the reason why interviews were conducted in this study to clarify some confusing name structures.

The family name is located at the end of an English full name. It serves to address the name of the ancestor of a person and therefore cannot denote gender. As mentioned by Lasker (1983), family names first appeared in the $13^{\text {th }}$ century, much later than given names. In today's time, English family names are mainly used in formal communication and legal documents. The number of family names in English society is ample. According to Lasker (1983), there were 32,475 were family names documented as of the early 1980 os. In this study, out of 12,879 English female names in the database, there are 3,921 names which have a single family name, accounting for $31.32 \%$. The rest are names with a complex family name, with $68.68 \%$. Complex family names take different forms. These are marked as eight models (Model 1 - Model 8 in Table 4) and can feature

i. $\quad$ one root and one suffix (S) as in Brewster= Brewst (root) + er (suffix) or one root and one prefix (P) as in Atwood = At (prefix) + wood (root)

ii. two roots as in Richardson= Richard (root) + son (root)

iii. two single words as in Daniel-John= Daniel (word) + John (word)

iv. at least one complex name as in Goldstone-Smith $=[$ Gold (root) + Stone (root) $]+$ Smith (word)

In England as well as in other European countries, a woman usually has her family names legally changed into her husband's after marriage. Her original family name will be resumed if she is divorced or her husband dies. This custom is believed to lead to the appearance of several complex family names in the system (Bardsley, 1815). Other probable causes of English complex family names among women have also been suggested, including a combination of father's and mother's family names, originating from European elite's names, newly coined names from the original ones, or originating from European languages (Bardsley, 1815).

\subsubsection{Linguistic features of Vietnamese female names in comparison with English female names}

Vietnamese female names are presented in a reverse word order compared with English ones. A Vietnamese female name starts with a family name and ends with a given name. The middle name is placed between the family name and the given name.

In the Vietnamese culture, the given name is of utmost importance as it is the only required component to address oneself and others in oral and written communication. Formality is maintained by adding a title before the given name. For example, di Thảo [Aunt Thao] is a formal means of addressing a person named Thảo. Similar to the English language, the structure of Vietnamese given names can be categorized as simple or complex. However, it should be noted that Vietnamese complex given names are constructed from individual words while the complexity of English given names is shown by means of inflection with a prefix or a suffix added to the root. Among 12,936 Vietnamese female names surveyed, 7,781 had single given names, comprising $60.15 \%$. Complex given names occur in two types. Type 1 involves one main word and one supplement. For example, in the name Nguyễn Thị Thu Lan, Thu Lan as the given name is constructed from the main word Lan and a supplement Thu. This is to distinguish Thu Lan from other given names such as Hương Lan or Hồng Lan. In this study's database, 5,155 Vietnamese females are found to have this type of name, making up $38.85 \%$. Type 2 is coined by two independent single words whose meanings are semantically equal. For example, in the name Bùi Thị Xuân Thu, the given name Xuân Thu consists of two independent words Xuân [meaning Spring] and Thu [meaning Autumn]. The findings in this study reveal that 190 out of 12,936 names bear these complex features, which is equivalent to an insignificant percentage of $1.47 \%$. Often, in spoken language, only the last word in a complex given name is used. For example, a person with the name Bùi Thị Xuân Thu is often addressed as Thu, rather than Xuân Thu. There are only a few exceptions, for instance the given name Anh needs to be used in combination with a supplementary word as in Vân Anh or Lan Anh as the word Anh alone is homonymous with the noun anh, which is used to address an elder brother. 
The structures of Vietnamese female names are given in Table 5. As shown in the table, Vietnamese female names are less structurally complex than English ones. There are five different ways to construct a Vietnamese female name. The least popular model of family name belonged to model 6 with one name, accounting for 0.or\%. The highest frequency model of English female complex names was number 1 with 5929 names, comprising 39.83\%, in which the names with suffix far outnumbered those with a prefix, 5848 to 81 respectively. This was followed by model 2 and 3 with 3604 and 57 names, comprising $\mathbf{2 7 . 9 8 \%}$ and $0.44 \%$ accordingly.

Table 5. Structures of Vietnamese female names

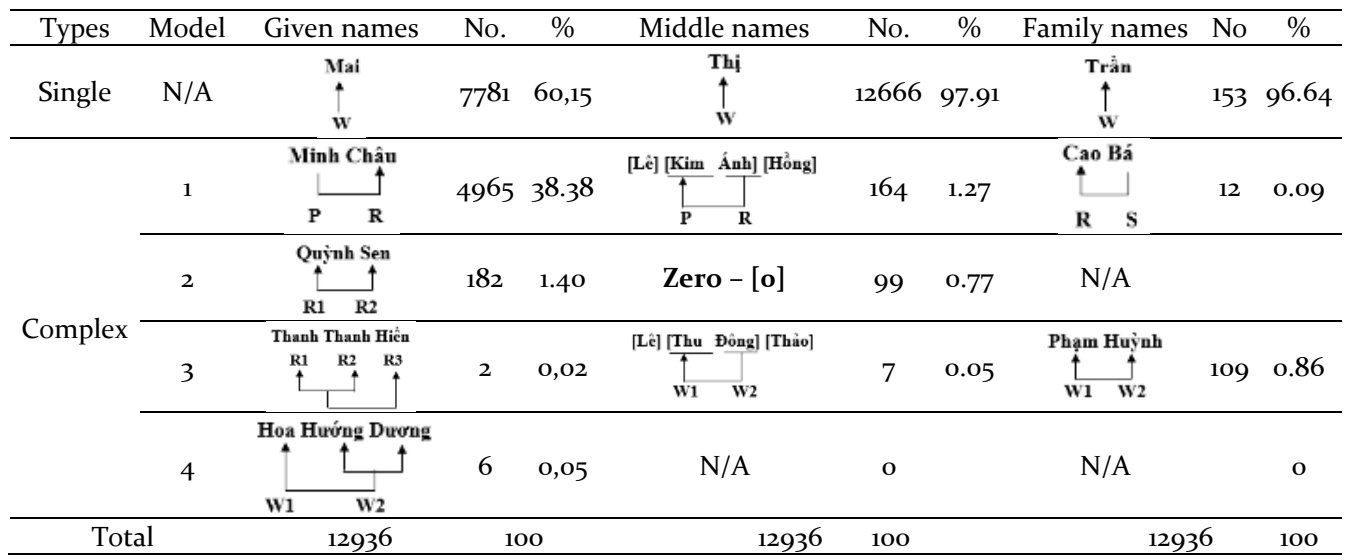

Regarding given names, Vietnamese female names are mostly characterised with a single given name structure, which comprises $60.15 \%$ of total cases. This is the same trend in English with the highest percentage being documented for single given names. Similarly, Vietnamese complex female names share the same feature with English complex female names when consisting of four models, the most frequent of which is model 1 containing one root and one affix. One difference is that model 3 in English only contains two independent words, that in Vietnamese three independent roots. Although Models 3 and 4 are the least popular in both female name systems, those in English far outnumber those in Vietnamese, with 40 and 8 names respectively. The popularity of single given names among Vietnamese females reflects the language features which is monosyllabic and the habit of Vietnamese people in using single names to call in daily life. Also, the increasing popularity of complex names with one root and one affix in both languages can be argued to have resulted from the rise in aesthetic needs (V. K. Nguyen, 2010).

However, there are a few differences in the structures of middle names in Vietnamese and in English. While in English, names without a middle name are the most popular, in Vietnamese, names with a single middle name are the most popular, accounting for 97.91\%. Female middle names in Vietnamese are supposed to have come into use later than family names. This is explained by V. K. Nguyen (1999) that middle names were forbidden and considered insulting by Wang Mang dynasty, an emperor reigning from $48 \mathrm{BC}$ and $\mathrm{AD}$ 23,. Nowadays, Vietnamese female middle names play a very important role in denoting gender, family relationship, and anesthetic connotation (T. T. Pham, 1996). English female middle names, meanwhile, are hardly recognized with an equally important role. Speakers of English mostly disregard the role of middle names in daily communication, either by omitting them when speaking or contracting them in writing.

Concerning family names, that many Vietnamese people carry the same family names is not uncommon (T. T. Pham, 1996, 2005). In this study, among 12,936 Vietnamese female names, there are only 153 single family names, accounting for $96.64 \%$. Nguyễn is the most common single family name, 
appearing in 4,020 cases (31.08\%). Since the Vietnamese language is non-inflectional, it is difficult for family names to be formed as opposed to the English language. On top of that, the origins of the Vietnamese were mainly limited to Chinese while English names may have originated from different ethnic origins (Jin, 2006; V. K. Nguyen, 2010; H. K. Pham, 2015; Tan, 2001). The inheritance of family names in Vietnam is attributed to the effort of clans to better manage the number of people and relatives within their community (H. K. Pham, 2015; T. T. Pham, 1996, 2005). Interestingly, very few female students could wear these complex family names and none had their names written in the clan's record books since females were not considered the heirs of the clan (Tran, 1984). This is mostly a tradition that discriminates against females in the old society of Vietnam. However, this mindset is still considered appropriate and common, especially in rural and remote areas of modern Vietnam (V. K. Nguyen, 2004; H. Pham, 2002). Complex family names Model 3 have been examined by many researchers who suggest a few causes behind their formations and operation to include the adoption of a child or the incorporation of mother's family name (H. Pham, 2002; H. K. Pham, 2015; T. T. Pham, 1996, 2005).

In brief, given, middle and family names of English and Vietnamese females had both single and complex structures. In English, single given names appeared far more regularly than single family names, with $98.6 \%$ and $31.32 \%$ respectively. Nonetheless, in Vietnamese, single structure was common for all the three components of name, with $60.15 \%$ of given names, $97.91 \%$ of middle names and $99.04 \%$ of family names having a single name structure.

\subsubsection{Comparison of the structures of English and Vietnamese female full names}

From the findings synthesized in the previous section, beside the disparities in the internal structures of each component of a name, female full names in both the English and the Vietnamese language differ in the position of given names and family names. While an English female full name starts with a given name and ends with a family name, a Vietnamese name has a reverse order. Since a family name represents a clan or kinship, it is questionable whether the order of components can infer the order of importance of the two components. Interviews with 50 English respondents revealed that given and family names are of equal importance in the English society but the situations in which each name type is used are different. Family names, for example, are used in formal situations with a system of addressing words preceding them, such as Mrs. or Miss. Given names, on another note, are utilized in informal situations without an addressing word. In Vietnamese, given names are the most important of three names and used in both written and oral communication. The only difference is that in formal situations, an abundant range of addressing words is employed to show respect to people of superior positions or age, such as anh [brother], chị [sister], cô [aunt], di [aunt], chú [uncle], bác [uncle], ông [Mr.], bà [Mrs.], and so on. Scarcely are family names used in communication, except for Vietnamese prominent political figures, such as Bác Hồ [President Ho Chi Minh], Bác Tôn [Tôn Đức Thắng], or Bác Giáp [General Võ Nguyên Giáp] (Ngo, 2006; H. Pham, 2002).

Several studies including van Langendonck (2007), Farkas (2017) and T. T. Pham (2005) hypothesize that given names in English initiate full names to emphasize individuality, whereas in Vietnamese, the initiating of family names highlights the importance of one's original background and collectivity. Individualism is the typical cultural feature of the Europeans, including English people, which demonstrates the people's tendency and preference to display independence and self-expression (Booth, 1869; Hofstede, 2001). Collectivism, in contrast, has been known as a typical cultural quality of Asians, including Vietnamese. It features the interdependence and connection within a group of people. The order of a name in both the English and Vietnamese cultures can disclose the above features (Tran, 1984). Albeit female names in both languages could be constructed from two to five words, the popularity and the models of each type were not similar in the two language systems. Specifically, in English, longer names are less common than shorter ones. Two-word names account for $94.48 \%$ of all English female full names surveyed whereas only $0.03 \%$ is recorded for five-word name accordingly. In Vietnamese, however, three-word names account for the highest percentage of all 
Vietnamese full names surveyed (58.74. Two-word names are the least popular with only 10 names, comprising $0.07 \%$ (Figure 1.)

Regarding naming patterns, there are a total of 24 models of female name structures in English and 21 in Vietnamese. For the former, albeit the most common structure, two-word names take the form of two models, the fewest of all. Four-word names have up to eleven models, the most significant figure of all the models in both languages. In Vietnamese, however, two-word and three-word names have the most models, eight for both whereas five-word names have the fewest, only one model.

The popularity of two-word names with the widespread absence of middle names among English females could have been due to the result of the industrial revolution. Advancements in technology led to profound shifts in almost all aspects of the society, even the disappearance of middle names which used to be popular among the aristocracy (Farkas, 2017; V. K. Nguyen, 1999).

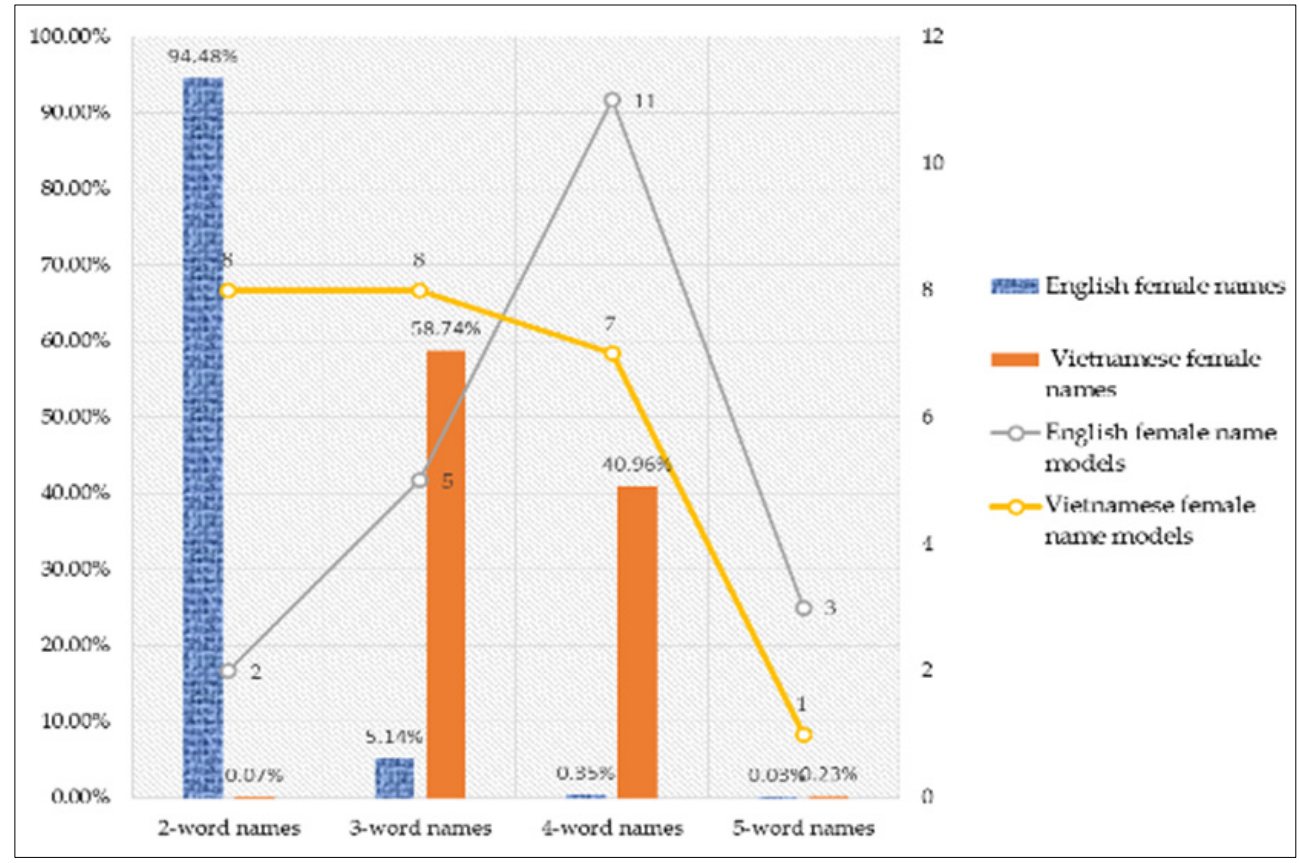

Figure 1. English female names and name models

\subsection{Semantic features of English and Vietnamese female names}

\subsubsection{Female given names}

As mentioned in the review of the literature, while there are different arguments for and against whether given names carry meanings, this study advocates the side that recognizes the existence of connotation and denotation meanings of names in both languages. However, the meaning that is mentioned in this research is pre-suppositional meaning, not the lexical meaning. From 12,879 English names and 12,936 Vietnamese names available in the database, 500 names in each language were randomly selected for semantic analysis. The similarities and differences in the semantic features in the naming process in the two languages are summarized in Table 6. 
Table 6. Semantic features of female given names

\begin{tabular}{|c|c|c|c|c|c|}
\hline \multicolumn{2}{|l|}{ Semantic features } & \multicolumn{2}{|l|}{ English female given names } & \multicolumn{2}{|l|}{ Vietnamese female given names } \\
\hline Groups & Sub-groups & Example & $\%$ & Example & $\%$ \\
\hline \multirow{8}{*}{$\begin{array}{l}\text { Meanings related to } \\
\text { natural events or } \\
\text { phenomena }\end{array}$} & Animal & Dove, Bunny, Starlyn & 1.0 & Yến [Swallow], Phượng [Phoenix] & 1.0 \\
\hline & Vegetation & Camelia, Jasmine, Lily & 2.2 & Lan [Orchid], Cúc [Daisy] & 10.8 \\
\hline & Season & Summer, Sunny & 2.6 & Xuân [Spring], Thu [Winter] & 2.2 \\
\hline & Color & $\begin{array}{l}\text { Auburn, Blanche, } \\
\text { Gwenda }\end{array}$ & 1.0 & Hồng [Pink], Lam [Blue] & 3.6 \\
\hline & Material & Pearl, Rubie, Margaret & 7.6 & Ngọc [Pearl], Châu [Perlite] & 5.8 \\
\hline & Direction & $\mathrm{N} / \mathrm{A}$ & o & Đông [East], North [Bắc] & 0.6 \\
\hline & Typography & N/A & o & Thủy [Water], Hằng [Moon] & 15.0 \\
\hline & & & $14.4 \%$ & & $39 \%$ \\
\hline \multirow{6}{*}{$\begin{array}{l}\text { Meanings related to } \\
\text { social events or } \\
\text { phenomena }\end{array}$} & Religion-related & Valentina, Sebastian & 42.2 & $\mathrm{~N} / \mathrm{A}$ & o \\
\hline & Places & $\begin{array}{l}\text { Alexandria, Britany, } \\
\text { Chelsea }\end{array}$ & 9.6 & Hương An [in Hue City] & 13.6 \\
\hline & Culture (art works) & Cordena (in King Lear) & 15.4 & Kiều [Thúy Kiều] & 8.0 \\
\hline & $\begin{array}{l}\text { Human-related (e.g. from } \\
\text { aristocratic addressing, pet } \\
\text { forms, personal wishes, } \\
\text { parents' or sibling's names) }\end{array}$ & $\begin{array}{l}\text { Ashley, Regina, Joy, Lisa, } \\
\text { Beth (from Elizabeth) }\end{array}$ & 16.8 & $\begin{array}{l}\text { Lý, Trần, Lê, Vũ, Chung [Faithful] } \\
\text { Mỹ Linh [Singer], Thắng [brother's } \\
\text { name is Chiến to make a } \\
\text { compound Chiến Thắng, meaning } \\
\text { victory] }\end{array}$ & 29.8 \\
\hline & $\begin{array}{l}\text { Others (numbers; foreign } \\
\text { names) }\end{array}$ & $\begin{array}{l}\text { April } \\
\text { Kinga (German) }\end{array}$ & 1.6 & $\begin{array}{l}\text { Hai [Two], Ba [three], Lục [six] } \\
\text { Ana, Ny Na }\end{array}$ & 9.6 \\
\hline & & & $85.6 \%$ & & $61 \%$ \\
\hline
\end{tabular}

As revealed from Table 6, female given names in English and Vietnamese convey a wide range of meanings, from natural to social events and phenomena. Names are more likely to be given after a social phenomenon than a natural event in both languages. Concerning connotation meanings, almost all names carry the typical beauty of femininity. In case the given names are related to animals, those animals are typically tiny and loveable, such as Dove, Bunny in English or Yến (Swallow) or Phượng (Phoenix) in Vietnamese. In case the names refer to human-related characteristics, they tend to carry the elegance and grace of females. Such beauties and aesthetics in meanings of names express the aspirations, expectations, and wishes for a bright, happy, and successful future of the named children in both cultures.

Since English is an inflectional language, the formation of new names based on the available names is far easier and more common in English than in Vietnamese. In support of Imomov and Kuldashev (2020), the findings of this study reveal that English given names of all semantic groups can experience word-formation processes, including suffixation, shortening and phonological modification. Some typical instances are Margaretta from Margaret, Deb from Debora, or Sharyn from Sharon. In Vietnamese, new names are coined by means of word formations, such as phonological modification and compounding roots, for example Hà from Hạh, or Ngọc Lan from Ngọc and Lan.

Within the group of names carrying meanings related to nature, there were fewer English than Vietnamese female given names, with $14.4 \%$ and $39 \%$ respectively. Female names in the two languages share the meanings related to animal, vegetation, season, color and material. However, English names do not convey the meaning of direction and typography as in Vietnamese.

Within the group of names conveying meanings related to society, there is one group of female given names that exist in the official name system of English but not in that of Vietnamese. Those belong to the God-related name group. As explained by Dunkling (1977), names carrying God-related meanings originated from the Roman Catholic churches where baptism took place. After Great Britain separated from Roman in the $16^{\text {th }}$ century, names in the Christian Bible, particularly in the Old Testament, steadily became popular. Additionally, it is legally acceptable to use Christian names as official names in England. This allows God-related names to spread widely in England and accounted for up to $42.2 \%$ of English names. Dunkling (1977) categorizes English names related to religion into ten groups, three of which appear in the female name system (Deborah, Sharon, Elizabeth). In Vietnam, 
religion-related names, despite existing, are not officially and legally recognized. Instead, only names in birth certificates are officially recognized in informal and formal communication. Furthermore, Vietnamese naming is still heavily affected by naming taboo, therefore, names related to God, kings and other sacred entities remain avoided (Ha, 2009).

\subsubsection{Female middle names}

The second semantic category that is common in English female name system but not in Vietnamese is pet form, which refers to the shortened or suffixed forms of names. The pet form, such as Danielle from Daniel is becoming increasingly recognized as official names in English due to the ease in use and memorizing. In Vietnamese, however, pet form names are considered informal and only used at home.

As discussed above, middle names in English have almost disappeared. Middle names are coined using a limited number of available first and family names instead of being newly formed. Out of 500 English female names surveyed, only 20 names had middle names, which could be divided into two groups of meaning.

First, middle names carry the meanings of mothers' or grandmothers' family names. This practice is found to originate from the tradition in many European countries in the early $19^{\text {th }}$ century. European women after marriage had their family names converted into their husband's. Thus, using mothers' or grandmothers' family names as middle names for daughters or grand-daughters became more popular in upholding the family names of their maternal clan (McClure, 2016). Asema Daffodil Flower, for instance, is a female name that had its middle component 'Daffodil' - the mother's family names before marriage. This practice is affected by the society where the struggle for gender equality is rising and taking effects. The maintenance of maternal family names in their posterities' full name is recognized as a means of confirming the position of female relatives in the posterities' mindset. This type of name is also observed to exist in Vietnamese female family names to express the love of their mother and father $(\mathrm{Vu}, 2005)$.

Second is the middle names which are after the given names of their beloved or idolized people. This way of naming is believed to be affected by that of the Americans and thus remains novel. To illustrate, Christopher in Tracey Christopher Scott is mostly named after Christopher Columbus (14511506) to show parent's appreciation for the discoverer of the continent of America. Likewise, Celine in Kerrie Celine Parry reveals that the parent(s) is a fan of Celine Dion, a renowned French singer.

According to the answers of respondents to the interviewing questions, it is revealed that several Vietnamese female middle names are believed to contribute to the aesthetic level of a full name. To illustrate, Minh Anh, Diễm My, Hồng Trà are accordingly considered more beautiful than single Anh, My and Trà. For that reason, contrary to the downward trend that English female middle names have registered, an upward trend in popularity and in variety can be witnessed in the number of Vietnamese female middle names.

Table 7. Semantic features of female middle names

\begin{tabular}{|c|c|c|c|c|}
\hline \multirow[t]{2}{*}{ Semantic features of middle names } & \multicolumn{2}{|c|}{ English female middle names } & \multicolumn{2}{|l|}{ Vietnamese female middle names } \\
\hline & Example & $\%$ & Example & $\%$ \\
\hline Named after mother's given name & Asema Daffodil Flower & 2.4 & N/A & o \\
\hline Named after idol/beloved person & Tracey Christopher Scott & 0.4 & $\mathrm{~N} / \mathrm{A}$ & o \\
\hline Related to female gender & & o & Đặng Thị Bình, Thúy Anh & 22.6 \\
\hline Related to kinship & & o & Hồng Anh (Hồng is mother's middle name) & 0.9 \\
\hline $\begin{array}{l}\text { Related to objective entities (e.g. precious } \\
\text { objects, appearance, color, beautiful soul) }\end{array}$ & & o & $\begin{array}{l}\text { Ngọc [Pearl], Kim [Gold], Hạnh [Good- } \\
\text { natured], Hồng (Pink) }\end{array}$ & 58 \\
\hline $\begin{array}{l}\text { Representing wishes (e.g. for wealth, peace, } \\
\text { happiness) }\end{array}$ & & o & Quý [Precious], Phúc [Luck], An [Peace] & \\
\hline
\end{tabular}

As shown in Table 7, Thị is the most common middle name for Vietnamese females. Thị, as discussed in the previous section, is indicative of female gender in Vietnamese. However, its use has undergone 
changes in line with social changes, particularly with regard to gender equality. Specifically, the word first appeared in ancient Chinese society in 475-331 BC. In Chinese character, the word depicted the wooden stick, with a snake-shaped upper end (氏), meaning family or clan (Chanh, 200o). When imported to Vietnam, the word kept its original meaning. However, it gradually lost its original meaning. It was feminized and became a common middle name indicating females. This is considered a common phenomenon of imported words that change their original meaning to fit the culture and uses of the target users (Mai, Vu, \& Hoang, 1997; V. K. Nguyen, 2007). Thi has almost disappeared in modern Vietnamese female names since it is considered old-fashioned and even interfering with the beauty of the full names. Out of 500 full names surveyed, only 87 names had Thi as a middle name, comprising $17.4 \%$.

\subsubsection{Female family names}

As discussed in the literature review, Vietnamese family names do not carry meanings, so in this research Vietnamese female family names are regarded as meaningless. In this section, only English family names are investigated since they are found to have clear origins and carry certain meanings. The family name, which can be used as an independent naming unit in communication, is indispensable to an English female full name. It has been found that changes in family names are closely related to the historical and socio-cultural progress of a nation (Bardsley, 1815). The number of family names in English is vast, with diverse inflections. Yet, the semantic features of English female family names are found to be limited to three major groups, as shown in Table 8 .

Table 8. Semantic features of English female family names

\begin{tabular}{llc}
\hline Meaning & Example & $\%$ \\
\hline Referring to employments & Abbot, Chancellor, Boniface, Brewster , Cohen, Baker & 46.6 \\
Referring to place names & & 32.8 \\
- mentioning places & Aris, Paris, Conway, Ellenberger & 21.3 \\
- describing places & Atthewode (at the wood), Underhill (under the hill) & 9.5 \\
Referring to relationships & & 20.6 \\
- Father's given name + 's' & Carole Andrews (= Carol Andrew's = Andrew's Carol) & 3.2 \\
- Father's given name + 'son' & Wilson, Emerson, Thompson & 9.6 \\
- Prefix + father's given name & MacDonald, O'Connor & 7.6 \\
\hline
\end{tabular}

As shown in the table, English female family names connote the relationships within a family, or the area where a person is attached to or his or her employment. The most common semantic feature is that referring to work positions and employments with $46.6 \%$ family names falling into this category. The profession indicated by means of a name can be attached to a person by others. Reaney and Wilson (1991) explain that during the Norman time, many positions such as Steward or Chamberlain were passed down to the next generation. This led to the popularity of family names referring to careers and work positions. Being named after one's job is meaningful but could trigger the discrimination among social classes. For example, Bellyester refers to a person who make bells and Sporoner refers to a person who make nails. There also exist cases when it is confusing which content the name refers to. Bridge, Bridger and Bridgeman, for example, express either a place (bridge) or a person who bridged or made bridges or guarded at the bridge (bridger or bridgeman).

The second most common semantic feature of English female family name is those referring to place names, accounting for $32.8 \%$. This finding echoes the claim by Reaney and Wilson (1991) that the number of family names connoting place names is relatively large and there are two types of these family names. One refers directly to the place name, whereas the other refers to the features of that place (Bardsley, 1815; T. T. Pham, 1996, 2005). To illustrate, Aris is a place in England and Conway in Wales. The other refers to a location or a geographical trait of one place. For instance, Atwood means 
at the wood. The least common semantic feature of female family names in English is related to family relationships, namely names suffixed with an $-s$ or -son to indicate the possession of that person. Some instances found in the female full names are Lisa Clements meaning Clement's Lisa or Sophie Daniels meaning Daniel's Sophie. Otherwise, prefixes like Mac- or Mc were also added to family names, meaning the child of. To illustrate, MacDonald means Donald's child or O'Conor means Conor's child.

\subsection{Naming in relation to socio-cultural factors}

The human being, as a social product, has names which bear the social and cultural characteristics of a specific community. English and Vietnamese female names are of no exception as they feature the social and cultural characteristics of English-speaking and Vietnamese-speaking communities. The social roles that names have in either the Vietnamese or the English language are identical, namely to refer to an individual, differentiate the individual from others, and accompany them for their whole life. Names play a major part in people's social interactions, political involvement and in economic life (Jin, 2006). Nonetheless, each naming system has a different approach to the concept of names. In English, names play the role of labelling or tagging a person, whereas in Vietnamese, names are considered a united block with the person (Le, 2002). Therefore, name changing in England can be processed with ease. According to the National Association of Citizens Advice Bureaux (NACAB) (2010), people can change their first name or surname or rearrange their existing names without having to follow bureaucratic legal requirements. There are also services for changing names which can help the process easier and quicker. UK Deed Poll Service is an example of an entity which helps with changing female names after they are married, divorced, widowed, or change gender. Contrarily, in Vietnam, although it is not illegal to change a name, having one's name changed requires a long and complicated procedure with a lot of documents. The reason behind such complexity remains controversial. Culturally, changing names is treated as changing one's personalities (T. T. Pham, 2005).

The order in which different components of names are presented has been known to embed cultural meanings. As mentioned earlier, female names in English and Vietnamese both constitute a given name, a family and sometimes a middle name, yet these are arranged in a reverse order in the two languages. The initial position in a full name is believed to convey the importance of that name (T. T. Pham, 2005; Tan, 2001). The English given names initiating a full name can be interpreted as a means of emphasizing and focusing on the 'self', which displays individualism. The Vietnamese last names initiating a full name, meanwhile, can be interpreted as a means of highlighting collectivism. Such difference in the structure of names somehow reflects the typical difference between the western culture and eastern culture. One values the freedom of thought and action of individuals. The other appreciates family and genetic relationships within a community.

Naming taboo is another major difference between the two cultures. If Vietnamese naming taboo remains common in society, which does not exist in English. As noted, in the Vietnamese culture, a child cannot be named after gods, kings, saints or any other sacred figures in their clans as this is considered insulting or unlucky. This practice can be explained culturally as Vietnam is an agricultural country where people mainly make their living from their farms (Tran, 1999). The power of gods is trusted to bring luck, happiness, and good weather for farming practices. By avoiding gods' and kings' names, people can stay away from punishment for being disrespectful and receive blessings. Historically, name avoidance was a commonly practiced custom in the time reigned by Nguyen King (T. T. Pham, 2005). In the modern time, naming avoidance is widely affected by feng shui. According to feng shui, a name does not only carry information about a person's life but also determine his or her destiny, health, career, marriage and happiness (Ha, 2009). Many parents are believed to refrain from giving their children names that are phonologically inharmonious or culturally offensive (Ha, 20o9). In English, however, people consider naming after those sacred or superior people an honor. Jin (2006) and V. K. Nguyen (2010) refer to power distance when discussing the taboo-or-honor phenomenon in the Vietnam and Chinese naming system. Hofstede (2001) further explains that cultures with high power distance accept inequality as the cultural norm, whereas those with low power distance tend to 
favor equality between members of society. On introducing the power distance index, Hofstede (2001) gives Vietnam a score of 70 and Britain 35. Another point to note in naming is the popularity of hypocoristic names in Vietnamese culture and pet names in English culture. Vietnamese hypocoristic names often vary from official names in terms of phonology whereas pet names in English in terms of morphological, usually shortened form. For example, the official name of a Vietnamese female is Gia Hân and her pet name is Cỏ. Cỏ means grass in English, and usually refers to a female. In English, usually, a girl's name is Catherine, which can be shortened and used by family members or friends as Kat. As such, from a Vietnamese pet name, it is almost impossible to guess his or her official name as opposed to names in English.

Historical progress also contributes to the distinction in the origins and meanings of English and Vietnamese female names. Specifically, English history underwent the colonization, simulation, and integration of several European countries, eleven of which were found to be depicted in the names of English females. Names of English females bear the linguistic traits of languages from eleven origins, namely Hebrew, Continental German, old English, Insular Celtic, ancient Greek, Latin, English vocabulary, English creations, modern English, Arabic, and other languages (V. K. Nguyen, 2010). Vietnamese history, on another note, was profoundly affected by the Chinese culture for thousands of years. Therefore, many Vietnamese female names are Chinese-rooted.

In English, addressing is only available in formal situations where such titles as Miss or Ms. are attached to the family name. In Vietnamese, this addressing system is various and more complex. As explained by Luong (1990) and V. K. Nguyen (1999), Vietnamese terms of reference can disclose the social relationship, age difference, sex, social status, relationship status and feelings between the speaker(s) and the person(s) referred to. Since how one is addressed is a means of the speaker expressing politeness and respect to the addressee, Vietnamese people most of the time ask for the age of the other speaker(s), even with strangers, to properly address each other. Terms for addressing females in Vietnamese are listed in Table 9.

Table 9. Addressing system in the Vietnamese language (adapted from Cooke, 1968, p. 135)

\begin{tabular}{llll}
\hline Term & Literal meaning & Usage in communication & Interaction of terms \\
\cline { 2 - 2 } & Great Grandmother & To a very old person & Cụ-Cháu \\
Bà & Grandmother & Among female equals or to an elderly person & Bà-tôi/ Bà-cháu \\
Mẹ & Mother & To mother & Mẹ-Con \\
Bác & Parent's older sister & Uncle/aunt older than mother of the speaker & Bác-Cháu \\
Cô & Father's younger sister & To auntie & Cô-Cháu \\
Dì & Mother's younger sister & To auntie & Dì-Cháu/con \\
Chị & Older sister & To older sister/ To older female (formal or informal) & Chị-Em \\
Em & Younger sister & To younger sister/ To younger female & Em-Chị \\
Con & Offspring & To children (biological or non-biological) & Ba/Mẹ/Dì/Chú/Bác \\
Cháu & Niece or nephew & To cousin children or any children & Cháu-Bác/Chú/Dì \\
\hline
\end{tabular}

As can be seen from the table, kinship terms are used not only to address people of the same family but also strangers. This resonates with what several researchers, for example Luong (1990), H. Pham (2002), and Ho (2003), have found. Apart from the kinship terms available in English, Vietnamese address system also contains other terms that are not available in English. Some examples concerning female are bác [older aunt], di [younger aunt or stepmother], or chị [older sister cousin]. In addition to kinship terms, Vietnamese people also use status terms to refer to a person's occupation, such as đồng chí [comrade], cô [female teacher], giáo su [professor], or bác sĩ [doctor] (Ngo, 2006). In English, occasionally, professor and doctor are used in academically or medicinally formal situations.

Regarding one's gender indicated through names, both English and Vietnamese female names mostly bear femininity, including beauty, grace, and elegance. English female names differ in their phonological and morphological rules. According to Culter, Macqueen, and Robinson (1990), most English female names have the first syllable unstressed. Olivia, Amelia, Elizabeth, and Alisa are some 
examples. Meanwhile, male names often have the first syllable stressed. Culter et al. (1990) add that the last syllables in female names are mainly [ə] and [i], whereas male names mostly end in [k], [s], [t]. This phenomenon is explained by Hough (2000) based on the origin of names: Most female names originate from French and Latin, yet male names from German and the Bible. Although there exist no phonological and morphological like that in Vietnamese name system, gender discrimination is expressed via the middle names. As discussed above, female middle names contain very typical female words, particularly Thị, Diệu, Thúy, Thùy, and so on.

Gender discrimination is also featured with the name changing of women after getting married. As aforementioned, this practice was more popular in England than in Vietnam in the old time. In England, changing a woman's family name after getting married is studied to have dated back from the $14^{\text {th }}$ century (Thwaites, 2013). In this period, a married woman was considered losing everything even the family name. This notion did not change until the $15^{\text {th }}$ century when women changing family names were somehow considered a commitment between husband and wife. Until the $19^{\text {th }}$ century, most English women still took their husband's family names. Today, this practice has received much protest from a lot of modern women who fight for gender equality (Thwaites, 2013). The year 1972 marked a move in women's right to choose whatever names they wanted to have. As revealed from Eurobarometer Standard (1994), in 1994, there were 94\% of English women who changed their family names into their husband's after they got married. This figure experienced a downward trend in the past decades until 2013 and 2019 when it lowered to $75 \%$ and $54 \%$ respectively.

In Vietnam, under the profound impact of Confucianism, women have their given names converted into their husbands, and then oldest son and then oldest grandson. The life of a woman is generally considered to be attached to their husband and other female members of the family. However, this practice in Vietnam was not documented as officially as in England. Instead, name changing was used in daily informal communication. Since the name during her bachelorette time was not mentioned any more, it was often obliterated for the rest of the woman's life. In the modern days, such practice is scarce, apart from in rural areas of Vietnam. The changes tend to occur unnoticeably without as many protesting movements for equal rights as in England (Chanh, 2000; V. K. Nguyen, 2010; T. T. Pham, 1996; Tran, 1984, 1999).

\section{Concluding Remarks}

The research has provided an insight into English and Vietnamese female names in terms of linguistic structures, meanings, and cultural features. It can be concluded that among the major differences in the three aspects investigated, English and Vietnamese female names share several similarities. One of the most obvious resemblances is the femininity enclosed in the female names. Regarding the linguistic structures, it is found that both Vietnamese and English female names have single and complex names with up to eleven models. Also, since the English language is inflectional while the Vietnamese language is not, there are more models in given, middle and family names of English than of Vietnamese. In addition, female names in both languages convey meanings of several kinds, which are either denotational or connotational. While English female middle names are not important and thus often omitted or contracted, those in Vietnamese can be gender-specific or add to the aesthetics of the full names. While English family names in English are as important as given names in communication, family names in Vietnamese only take the responsibility of upholding the clan's names. Culturally, names convey the cultural and historical characteristics typical for a country. The research finds that the naming avoidance remains common in Vietnam but not in England. The naming practices in the two languages also differ due to the differences in religious practices and beliefs. Gender discriminations are traced in names of both languages, including the suffixes in English and the middle names in Vietnamese. 


\section{References}

Algeo, J. (1992). Onomastics. In T. McArthur (Ed.), The Oxford companion to the English language (pp. 727-729). Oxford: Oxford University Press.

Anderson, J. M. (2007). The grammar of names. Oxford: Oxford University Press.

Anderson, J. M. (2015). Names. In J. R. Taylor (Ed.), The Oxford handbook of the word (pp. 599-615). Oxford: Oxford University Press.

Bardsley, C. W. E. (1815). English surnames: Their sources and significations. London: Chatto and Windus.

Bhat, D. N. S. (1979). Referents of noun phrases. Pune: Postgraduate and Research Institute, Deccan College.

Booth, A. J. (1869). Robert Owen: The founder of socialism in England. London: Trübner \& Company Publisher.

Chanh, T. V. (200o). Từ điển Hán Việt hiện đại [Modern Chinese-rooted Vietnamese dictionary]. Hochiminh City: Youth Publisher.

Coates, R. A. (2006). Names. In R. M. Hogg \& D. Denison (Eds.), A history of the English language. Cambridge: Cambridge University Press.

Colman, F. (2014). The grammar of names in Anglo-Saxon England: The linguistics and culture of the old English onomasticon. Oxford: Oxford University Press.

Cooke, J. (1968). The pronominal reference in Thai, Burmese, and Vietnamese. Berkeley, CA: University of California Press.

Courtenay, J. N. B. (1972). A Baudouin de Courtenay anthology: the beginnings of structural linguistics. Bloomington, ID: Indiana University Press.

Culter, A., Macqueen, J., \& Robinson, K. (1990). Elizabeth and John: Sound pattern of men and women's names. Journal of Linguistics, 26(2), 471-482.

Dao, D. A. (1960). Chinese-Vietnamese dictionary. Hochiminh City: Khai Tri Publishing House.

Dunkling, L. (1977). First name first. London: Universe Publishing House.

Edmondson, J., \& Nguyen, V. L. (1997). Tones and voice quality in modern northern Vietnamese: Instrumental case studies. Mon-Khmer Studies, 28(35), 1-18.

Eurobarometer Standard. (1994). Public opinion in the European Union. Brussels: European Commission.

Farkas, T. (2017). Farkas, T. Onomastics Today: An International Overview. Debrecen: International Congress of Onomastic Sciences.

Ha, S. (2009). Những điều kiêng kị khi đặt tên [Naming taboos]. Hanoi: Hanoi Publisher.

Hayn, E. (2016). You name It? Everyday discrimination through accustomed perception of personal names. Berlin: Humboldt University.

Ho, D. T. (2003). Vietnamese-English bilingualism: Patterns of code-switching. London: RoutledgeCurzon.

Hofstede, G. (2001). Culture's consequences: Comparing values, behaviors, institutions, and organizations across nations. Thousand Oaks, CA: SAGE Publishing.

Hough, C. (2000). Toward an explanation of phonetic differentiation in masculine and feminine personal names. Journal of Linguistics, 36(1), 1-11.

Imomov, E., \& Kuldashev, A. M. (2020). Semantic features of proper names in English and Uzbek. ISJ Theoretical $\mathcal{E}$ Applied Science, 1(81), 740-743.

Jin, Y. (2006). A cross-cultural study of Chinese and English names. US-China Foreign Language, 4(11), 1-16.

Kripke, S. A. (1972). Naming and necessity. Oxford: Reidel.

Lasker, G. W. (1983). The frequencies of surnames in England and Wales. Human Biology, 55(2), 331-340.

Laversuch, I. M. (2010). Margarete and Sulamith under the Swastika: Girls' names in Nazi Germany. Names, 58(4), 219-230.

Le, T. H. (1992). Cách đặt tên chính của người Việt [The naming practice of official names among the Vietnamese]. HoChiMinh City: Social and Science Publisher.

Le, T. H. (2002). Họ và tên người Việt Nam [Vietnamese family names and given names]. Hanoi: Social Scientific Publisher.

Le, T. H. (2013). Nhân danh học Việt Nam [Anthroponomastics in Vietnam]. Hochiminh City: Youth Publishing House.

Luong, V. H. (1990). Discursive practices and linguistic meanings: The Vietnamese system of person reference. Amsterdam and Philadenphia: John Benjamins.

Lyons, J. (1977). Semantics. Cambridge: Cambridge University Press.

Mai, N. C., Vu, D. N., \& Hoang, T. P. (1997). Cơ sở ngôn ngũ học và tiếngViệt [Linguistic bases and the Vietnamese language]. Hanoi: Education Publishing House.

McClure, P. (1981). Nicknames and petnames: Linguistic forms and social contexts. Nomina: Journal of the Society for Name Studies in Britain and Ireland, 5(8), 63-33. 
McClure, P. (2014). Explaining English surnames: Linguistic ambiguity and the importance of context. Part two: Interpreting the modern data. Nomina: Journal of the Society for Name Studies in Britain and Ireland, 37(84), 109-141.

McClure, P. (2016). A short history of English personal names. Oxford: Oxford University Press.

Mill, J. S. (1884). A system of logic, ratiocinative and inductive: Being a connected view of the principles of evidence and the methods of scientific investigation. New York: Harper.

Motschenbacher, H. (2020a). Corpus linguistic onomastics: A plea for a corpus-based investigation of names. $A$ Journal of Omnomastics, 68(2), 88-103.

Motschenbacher, H. (2020b). Greece, the Netherlands and (the) Ukraine: A corpus-based study of definite article use with country names. Names, 6(8), 1-16.

National Association of Citizens Advice Bureaux (NACAB). (2010). Change of Name. Retrieved February 20,2020 from http://www.adviceguide.org.uk/index/family_parent/family/changeofname.htm.

Ngo, T. (2006). Translation of Vietnamese terms of address and reference. Translation Journal, 10(4), 92-97.

Nguyen, T. C. (1975). Nouns in modern Vietnamese. Hanoi: Social Science Publishing House.

Nguyen, V. K. (1999). Ngôn ngũu học xã hội: Nhũng vấn đề cơ bản [Socio-linguistics: The basic issues]. Hochiminh City: Social Science Publishing House.

Nguyen, V. K. (2004). Xã hội học ngôn ngữ về giới: Kỳ thị và kế hoạch hoá ngôn ngữ chống kỳ thị đối với nữ giới trong sử dụng ngôn ngữ [Sociolinguistics on gender: Naming taboo and planning the language against gender discrimination in language use]. Sociology, 2(86), 25-38.

Nguyen, V. K. (2007). Foreign words in Vietnamese. Hanoi: Education Publishing House.

Nguyen, V. K. (2010). A cross-cultural approach to personal naming: Given names in the systems of Vietnamese and English. (Doctoral dissertation). University of Sussex, Sussex.

Nyström, S. (2016). Names and meaning. In C. Hough (Ed.), The Oxford handbook of names and naming (pp. 39-51). Oxford: Oxford University Press.

Oelke, D., Kokkinakis, D., \& Malm, M. (2012). Advanced visual analytics methods for literature analysis. In K. Zervanou \& A. v. d. Bosch (Eds.), Proccedings of the 6th workshop on language technology for cultural heritage, social sciences, and humanities (LaTeCH 2012) (pp. 35-44). Stroudsburg, PA: Association for Computational Linguistics.

Olenyo, M. M. J. (2011). What is in a name? An analysis of the semantics of Lulogooli personal names. International Journal of Humanities and Social Science, 1(20), 211-218.

Pham, H. (2002). Vietnamese: Gender addressing and self-reference in Vietnamese. In M. Hellinger \& H. Bussmann (Eds.), Gender across languages: The linguistic representation of women and men. Amsterdam: Benjamin.

Pham, H. K. (2015). An overview of names of the Chinese and the Vietnamese. Language and Culture, 7(237), 72-74.

Pham, T. T. (1996). Đặc điểm của lớp tên riêng chỉ người (chính danh) trong tiếng Việt [Characteristics of Vietnamese official personal names]. (Doctoral Dissertation). Hanoi.

Pham, T. T. (2005). Danh xưng học và tên riêng người Việt [Onomastics and Vietnamese personal names]. Hanoi: Vietnam Academy of Social Science.

Phillip, T., \& Weller, S. T. D. (1964). Rituale Romanum (Roman ritual). Chicago: The Bruce Publishing Company.

Reaney, P. H., \& Wilson, R. M. (1991). A dictionary of English surnames. East Sussex: Psychology Press.

Sloat, C. (1969). Proper nouns in English. Linguistic Society of America, 45(1), 26-30.

Ström, H. J., \& Levin, M. (2019). The Obama presidency, the Macintosh keyboard and the Norway Fiasco: English proper noun modifiers and their German and Swedish correspondences. English Language and Linguistics, $23(4), 827-854$.

Tan, P. K. W. (2001). Englished names: An analysis of naming patterns among ethnic Chinese Singaporeans. English Today, 17(4), 45-53.

Thien, N. (2019). Trong tên có chữ 'Thị' và cuộc tranh cãi xấu, đẹp không hồi kết [The middle name "Thi" and the fight over beauty and ugliness]. Zingnews, 13 March.

Thompson, L. C. (2005). A Vietnamese reference grammar. Hawaii: University of Hawaii Press.

Thwaites, R. (2013). The making of selfhood: Naming decisions on marriage, families, relationships and societies. Policy Press, 2(3), 425-439.

Tran, N. T. (1984). Về lịch sử, hiện tại và tương lai của tên riêng người Việt [On history, present and future of Vietnamese personal names]. Dân Tộc Học, 3(86), 11-20.

Tran, N. T. (1999). Vietnamese cultural bases. Hanoi: Education Publishing House.

Tse, G. Y. W. (2000). Pedagogical implications of prototype theory for the writing of English grammar textbooks: The case of proper names. In K. Nicolaidis \& M. Mattheoudakis (Eds.), 13th international symposium on theoretical and applied linguistics: Proceedings (pp. 490-50o). Thessaloniki: Aristotle University of Thessaloniki. 
Tse, G. Y. W. (2005). Corpus-based study of proper names in present-day English: Aspects of gradience and article usage. Frankfurt am Main: Peter Lang.

van Dalen-Oskam, K. (2012). Personal names in literature: A quantitative approach. In L.-G. Larsson \& S. Nyström (Eds.), Facts and findings on personal names: Some European examples (pp. 153-168). Uppsala: Kungliga Vetenskapssamhället.

van Langendonck, W. (2007). Theory and typology of proper names. Berlin: Walter de Gruyter.

van Langendonck, W., \& van de Velde, M. (2016). Names and grammar. In C. Hough (Ed.), The Oxford handbook of names and naming (pp. 17-38). Oxford: Oxford University Press.

Vartiainen, T. (2019). From Twig-skinny to Kate Moss skinny: Expressing degree with common and proper nouns. English Language and Linguistics, 23(4), 901-927.

Vu, T. K. H. (2005). Những đặc trưng xã hội-ngôn ngữ học của tên riêng chỉ người trong tiếng Việt [Social-linguistic features of personal names in Vietnamese]. (Master thesis). University of Science and Humanity, Hanoi.

Vuillemot, R., Clement, T., Plaisant, C., \& Kumar, A. (2009). What's being said near 'Martha'? Exploring name entities in literary text collections. In J. Stasko \& J. J. v. Wijk (Eds.), IEEE symposium on visual analytics science and technology, 2009: Proceedings (pp. 107-114). Piscataway, NJ: Institute of Electrical and Electronics Engineers.

Yeon, H. (2014). Names and taboos: A naming taboo and an ancestor-friendly naming practice. Korea Scholar, 22(1), 161-180. 